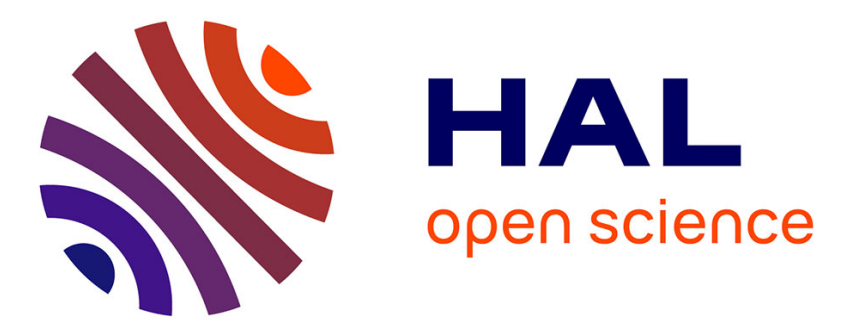

\title{
Space use and territoriality of wolverines () in northern Scandinavia
}

\author{
Jens Persson, Per Wedholm, Peter Segerström
}

\section{To cite this version:}

Jens Persson, Per Wedholm, Peter Segerström. Space use and territoriality of wolverines () in northern Scandinavia. European Journal of Wildlife Research, 2009, 56 (1), pp.49-57. 10.1007/s10344-0090290-3 . hal-00535233

\section{HAL Id: hal-00535233 \\ https://hal.science/hal-00535233}

Submitted on 11 Nov 2010

HAL is a multi-disciplinary open access archive for the deposit and dissemination of scientific research documents, whether they are published or not. The documents may come from teaching and research institutions in France or abroad, or from public or private research centers.
L'archive ouverte pluridisciplinaire HAL, est destinée au dépôt et à la diffusion de documents scientifiques de niveau recherche, publiés ou non, émanant des établissements d'enseignement et de recherche français ou étrangers, des laboratoires publics ou privés. 


\title{
Space use and territoriality of wolverines (Gulo gulo) in northern Scandinavia
}

\author{
Jens Persson • Per Wedholm • Peter Segerström
}

Received: 7 October 2008 /Revised: 25 May 2009/Accepted: 28 May 2009/Published online: 18 June 2009

(C) Springer-Verlag 2009

\begin{abstract}
Space use and territoriality influence population structure and dynamics and is therefore an important aspect in understanding the ecology of animals. We investigated spatial and temporal space use of wolverines (Gulo gulo) in northern Scandinavia. We estimated home ranges of 24 radio-marked individuals (17 females and seven males). Male home ranges (mean $669 \mathrm{~km}^{2}$; $\mathrm{SE}=211$ ) were significantly larger than female home ranges (mean $170 \mathrm{~km}^{2}$; Wilcoxon-Mann-Whitney; $P=0.001$ ) and encompassed or included parts of up to five different females. Home range sizes of reproducing $\left(170 \mathrm{~km}^{2} ; \mathrm{SE}=51\right)$ and barren $\left(171 \mathrm{~km}^{2} ; \mathrm{SE}=63\right)$ adult females did not differ. Wolverines in Scandinavia exhibit intrasexual territoriality, with male home ranges totally exclusive and female home ranges either exclusive or with little home range overlap. Overlap between wolverine territories is most likely explained by intrasexual tolerance and kinship.
\end{abstract}

Keywords Carnivore $\cdot$ Home range $\cdot$ Mustelid Overlap · Social organisation

\section{Introduction}

The spacing pattern of animals is the result of the tactics used by individual animals in their attempts to survive and

Communicated by P. Krausman

J. Persson $(\bowtie) \cdot$ P. Segerström

Grimsö Wildlife Research Station, Department of Ecology,

Swedish University of Agricultural Sciences,

73091 Riddarhyttan, Sweden

e-mail: jens.persson@ekol.slu.se

P. Wedholm

Örebro County Administrative Board,

Stortorget 22,

70186 Örebro, Sweden maximise reproductive success (Sandell 1989). Animals compete for different resources, such as food, shelter, and mates (Maher and Lott 1995). One way to compete is to exclude potential competitors from the area containing the resources (i.e., being territorial; Noble 1939; Schoener 1968; Brown and Orians 1970). A home range is defined as the area covered by the animals in their normal dayto-day activities and territory as that area which is defended against conspecifics (Burt 1943). Variation in home range size may lead to unequal division of resources among competitors, resulting in differential rates of growth, mortality, and reproduction (Adams 2001). Territorial behaviour can, thus, have strong effects on population structure and dynamics and is an important aspect in understanding animal ecology (Adams 2001).

The wolverine (Gulo gulo) is a solitary generalist predator and scavenger, occupying tundra, taiga, and forest zones of North America and Eurasia (Banci 1994). Because wolverine populations generally occur at low densities and occupy remote and rugged habitats, few studies of freeranging wolverines have been conducted. Only in recent years has fundamental knowledge on wolverine demography been gained (Persson et al. 2003, 2006, 2009; Krebs et al. 2004; Persson 2005). Published information about wolverine spatial dynamics originates from a few telemetry studies (Hornocker and Hash 1981; Whitman et al. 1986; Landa et al. 1998; Vangen et al. 2001).

Like most mustelids (Powell 1979), wolverines exhibit intrasexual territoriality and varying degrees of intrasexual overlap (Banci 1994). Spatial organisation in solitary carnivores is determined by different resources for each sex; female home ranges would be determined by food resources while male home ranges would be determined by the number and distribution of females (Sandell 1989). This corresponds with the polygamous mating system of wolverines, which predicts that male home ranges should be larger than females (Hedmark et al. 2007). 
Globally, the wolverine is classified as vulnerable (Mustelid Specialist Group 1996). Conservation concerns include primarily habitat fragmentation, overexploitation, and depredation conflicts with sheep and reindeer husbandry (Landa et al. 2000; Slough 2007; Zhang et al. 2007). The Scandinavian wolverine population's distribution and size declined markedly during the 1900s (Flagstad et al. 2004). Currently, $\geq 1 / 2$ of the Scandinavian wolverine population, estimated at about 780 individuals, reside in Sweden (Persson 2007) where it is classified as endangered (Gärdenfors 2000). The distribution of wolverines in Sweden largely overlaps with that of semi-domestic reindeer (Rangifer tarandus), which is the predominant prey of wolverines (Persson 2005). Locally, reindeer husbandry suffers from heavy predation by wolverines and other predators (Swenson and Andrén 2005). As a result, poaching and lethal control forms a substantial part of wolverine population dynamics in northern Scandinavia (Persson et al. 2009).

In light of current conflicts and lack of knowledge, more information is needed to understand spatial ecology of wolverines and to enable sound management of the species. Therefore, in this study, we examine space use and social organisation in wolverines. In particular, we assess age and sex specific home range size and territoriality.

\section{Materials and methods}

Study area

This study was conducted in and around Sarek National Park in northern Sweden above the Arctic Circle (Kvikkjokk: $67^{\circ} 00^{\prime} \mathrm{N}$, $17^{\circ} 40^{\prime} \mathrm{E}$ ). The climate is continental, and the ground is usually snow-covered from November to late May. The area is characterised by deep valleys, glaciers, and high alpine plateaus with peaks $\leq 2,000 \mathrm{~m}$ above sea level. The valleys are dominated by mountain birch (Betula pubescens), Scots pine (Pinus sylvestris), and Norway spruce (Picea abies), while mountain birch forms the tree line at 600-700 $\mathrm{m}$ above sea level (Grundsten 1997). Semi-domestic reindeer are managed exclusively and extensively by the indigenous Sámi people in the study area. The approximate density of wolverines were $1.4 / 100 \mathrm{~km}^{2}$ in the study area (Persson et al. 2006).

Animal capture and monitoring

We monitored wolverines from 1993 to 2000 . We captured and equipped juveniles (2-3 months old) with transmitters at rendezvous sites in early May to early June. All animals categorised as subadults were captured as juveniles and were hence of known age. Adults were captured on ground or were darted from helicopters (Arnemo and Fahlman 2007).
We radiotracked wolverines on average every second week by plane, complemented with additional groundbased telemetry. We estimated locations with triangulation (Kenward 2001), and the precision was given as estimated error-radius of $100-\mathrm{m}$ intervals around the location. Reproduction of adult females was determined from documentation of denning behaviour or observations of offspring or their tracks by means of radiotracking and observations on the ground (Persson et al. 2006).

Home range sample requirements

We used minimum convex polygon (MCP) sample size bootstrap in Animal Movement Extension (Hooge and Eichenlaub 1997) to find the required sample size for annual home ranges (Harris et al. 1990; White and Garrott 1990; Kenward 2001). We were unable to find an asymptote in a number of telemetry locations, even when only adult resident individuals with $\geq 30$ locations were used $(n=15 ; 100$ simulations). Therefore, we based sample size requirements for home range on a regression analysis to find a cut-off point where there was no positive correlation between home range size and number of locations (Dahl and Willebrand 2005).

Animals were considered resident if locations were strictly confined to a distinct area (Powell 2000). Furthermore, only resident animals that were alive and whose locations were distributed during the entire year under consideration were used. Annual home ranges were calculated in calendar years.

During 1993 to 2000, 24 individuals (17 females and seven males) fulfilled the stringent criteria for annual home range analyses and were used in analyses. Eleven individuals were monitored multiple years and provided sufficient data for multiple (two to four) estimates of home ranges. Their annual home ranges were used separately for comparison of different home range estimators (40 separate home ranges). Adult female home ranges from the same individual from different years were treated as individual units if they represented years with different reproductive status (reproductive or barren). However, when sufficient data were collected for a single individual for multiple years (with the same reproductive status), a mean annual home range was calculated (one barren and four reproducing adult females, two adult males) to avoid pseudoreplication.

Autocorrelation analyses

We used Schoeners' index (Schoener 1981; Swihart and Slade 1985) to control for autocorrelation in the location data (White and Garrott 1990; Kenward 2001). We calculated Schoeners' index for all individuals with annual home ranges and performed autocorrelation analyses with the Animal Movement Extension (Hooge and Eichenlaub 1997) in ArcView 
3.2. We considered location data statistically autocorrelated when index values were below 1 (Kenward 2001).

\section{Home range size}

We estimated annual home ranges for all individuals that met the sample requirements. Home range estimators have different statistical properties, and a single method may not be appropriate to answer all research questions (Harris et al. 1990). Therefore, we used two statistically different methods: the MCP (Mohr 1947) and the fixed kernel method (FK; Worton 1989). We used 95\% contours (FK95 and MCP95) to minimise influence of occasional excursions that could result in overestimates of range size (White and Garrott 1990). Fifty percent contours of kernel home ranges (FK50) were used as a measure of core area (Ackerman et al. 1990). Kernel estimators are suggested to be more accurate for estimation of home range size (Worton 1989; Seaman et al. 1999; Kernohan et al. 2001). Thus, home range sizes, overlaps, and relative differences between individuals of different sex and age are referred to FK95 estimates unless otherwise noted. We included MCP (100\%) for comparison with previous studies (Harris et al. 1990).

Fixed kernels were created with least squares cross validation for selection of the smoothing parameter $h$ (Seaman et al. 1999). Grid coarseness was allowed to vary across individuals. We performed all home range calculations in ArcView 3.2a (ESRI, Redlands, CA, USA) with Animal Movement Extension 2.0 (Hooge and Eichenlaub 1997) and Home Range Extension 0.9 (Rodgers and Carr 1998).

\section{Home range overlaps}

To examine territoriality, we calculated the proportion of exclusive home ranges and overlap between neighbouring individuals. Individuals were considered neighbours if they had contours (borders) within the distance of one home range radius $(8 \mathrm{~km})$. We quantified overlap of wolverine home ranges (FK95, MCP95), and core areas (FK50) were using theme-overlay routines in ArcView. We measured overlap size and calculated percent overlap of interacting individuals' home ranges as mean overlap and present it as an index (Minta 1992). We compared mean overlap in percent and size between age and sex categories. We calculated mean overlap as $=([$ overlap area $/ \mathrm{HRa}] \times$ $[$ overlap area $/ \mathrm{HRb}])^{0.5}$, where $\mathrm{HR}=$ home range, $\mathrm{a}=$ wolverine individual $a$, and $b=$ wolverine individual $b$.

Temporal association in home range overlaps

We measured the proportion of locations that were temporally associated in overlap areas simultaneously within $24 \mathrm{~h}$. Temporal association was calculated and quantified with simple ratio association indices (Cairns and Schwager 1987; Ginsberg and Young 1992). An index value of 1 indicates that all locations of both animals have been recorded at the same time in the overlap. A value of 0 indicates that individuals have not appeared in the overlap area during the same time. We assume that it is practically impossible to record an index value of 1 in the field. Therefore, we used a natural reference representing high association-level to evaluate the results. Association indices of each dyad were compared to a reference index calculated on interactions between wolverine mothers and their offspring during 1 year.

Simple ratio index was calculated as $=x /\left(x+y_{\mathrm{ab}}+\right.$ $\left.y_{\mathrm{a}}+y_{\mathrm{b}}\right)$, where $\mathrm{a}=$ wolverine individual $\mathrm{a}, \mathrm{b}=$ wolverine individual $\mathrm{b}, x=$ number of locations of $\mathrm{a}$ and $\mathrm{b}$ together in the overlap area (within $24 \mathrm{~h}$ ), $y_{\mathrm{ab}}=$ number of locations of $\mathrm{a}$ and $\mathrm{b}$ in respective home range outside overlap area, $y_{\mathrm{a}}=$ number of locations of a alone in overlap area, and $y_{\mathrm{b}}=$ number of locations of $\mathrm{b}$ alone in overlap area.

\section{Statistical analyses}

Because most data failed to approximate normal distributions and sample sizes were small, we used non-parametric tests (Siegel and Castellan 1988). Wilcoxon-Mann-Whitney twotailed tests for small samples were used to test for differences between two independent groups. Kruskal-Wallis test was used when three or more groups were compared. Spearman's rank correlation was used to analyse correlation between home range size and number of locations. Statistical significance was inferred at an alpha level $\leq 0.05$. All statistical analyses were performed in JMP 5.1 (SAS Institute 2000).

\section{Results}

We estimated 40 annual home ranges, which were used for comparison of home range estimators. After pooling multiple home ranges from the same individual, we used 28 home ranges from 20 adult wolverines for further analyses. We used 1,198 telemetry locations, and the mean triangulation error was estimated to be $583 \mathrm{~m}(\mathrm{SE} \pm 52)$. We used only locations with a triangulation error $<1,000 \mathrm{~m}$. Most (68\%) locations were taken during March to August. Locations were reported to be autocorrelated for only two individuals (one adult female and one adult male). Location data from both individuals continued to show autocorrelation even when locations within $48 \mathrm{~h}$ were removed, most likely a result of some biological restrictions, and they were included in the analyses.

Home range size

At 20 locations, there was no positive correlation between fixed kernel range size and number of locations for adult reproducing 
females (Spearman's rank correlation; $n=15, P=0.55$, $\left.r_{\mathrm{s}}=-0.1411\right)$, adult barren females $\left(n=9, P=0.93, r_{\mathrm{s}}=\right.$ $-0.035)$, or adult males $\left(n=4, P=0.23, r_{\mathrm{s}}=-0.5798\right)$. The result was similar for MCP. Thus, we considered a minimum of 20 locations sufficient for estimating annual home range size. However, one subadult resident female with 16 locations was included because no subadult females had $\geq 20$ locations.

Estimates of annual home range $(n=40)$ sizes differed significantly between methods (MCP100, MCP95, and FK95; Kruskal-Wallis test; $P=0.043)$. The fixed kernel (95) method generated larger home ranges on average than both polygon estimates (MCP100 and MCP95 pooled; Wilcoxon-Mann-Whitney; $P=0.035$ ).

Mean annual home range size (FK95; Table 1) of adult males $(n=4)$ was $669 \mathrm{~km}^{2}$ (median $599 \mathrm{~km}^{2}$ ) and ranged from 230-1,246 $\mathrm{km}^{2}$. Mean home range size (FK95) of adult barren females $(n=9)$ was $171 \mathrm{~km}^{2}$ and ranged from $25-603 \mathrm{~km}^{2}$. Mean home range size (FK95) for reproducing females $(n=$ 15) was $170 \mathrm{~km}^{2}$ and ranged from $48-805 \mathrm{~km}^{2}$. Median home range size (FK95) was 105 and $80 \mathrm{~km}^{2}$ for reproducing and barren females, respectively. Because neither mean (the same) nor median (Wilcoxon-Mann-Whitney; $P=0.57$ ) home range size differed between barren and reproducing females, all females were pooled and compared to adult male home range size. Adult males had significantly larger home ranges than adult females (Wilcoxon-Mann-Whitney; $P=0.001$ ).

Core areas (FK50) of adults were $15-20 \%$ of total home range size, for both males and females (Table 1). There was no difference in core area size between the two classes of females (Wilcoxon-Mann-Whitney; $P=0.52$ ).

Annual home range sizes for resident subadult males $\left(165 \mathrm{~km}^{2}\right)$ were approximately one third of adult ranges. One female resident subadult had a home range of $51 \mathrm{~km}^{2}$. Core areas of subadults were $40 \%$ for males and $25 \%$ for the female.

Home range overlaps

Home range overlap differed depending on the home range estimation method used (Table 2). Fixed kernel 95 resulted in a total of 40 overlaps, while MCP95 generated only 13 overlaps. Sixteen adult females provided 30 pairs of neighbouring home ranges (same year). Ten (33\%) home range pairs were exclusive, and 20 overlapped. Home range overlaps between adult females were generally small, with a mean overlap of $9 \%$ (Fig. 1; Table 2). Overlap sizes ranged from 0.01 to $46 \mathrm{~km}^{2}$ and covered at most $24 \%$ of both female home ranges. Core areas were generally exclusive between adult females except for one case. However, this overlap $\left(0.1 \mathrm{~km}^{2}\right)$ was an artefact generated by overlapping buffers (smoothing) around the locations. Annual home ranges of adult males $(n=6)$ were totally exclusive. However, there were only two neighbouring males in 1993 and three neighbouring males in 1994.

Home range overlaps (Table 2) between adult males and adult females $(n=10)$ were significantly larger than those between adult females (Wilcoxon-Mann-Whitney; $P=$ $0.018)$. Overlap sizes were up to $259 \mathrm{~km}^{2}$ and covered at most $48 \%$ of both home ranges. One male was partly covering home ranges of five adult females, and another male overlapped three females within his home range. One female home range was totally enclosed by a male home range.

The largest overlaps were found between two pairs of subadult and adult males, covering an average of $29 \%$ of integrated home ranges (Table 2). Overlap sizes were 61 and $164 \mathrm{~km}^{2}$, respectively. Mean overlap of adult females and subadult males (20\%) were similar to those of adult males and females $(0.17)$, but overlap sizes were smaller, probably because of relatively smaller home ranges. The subadult female had her home exclusive of other marked individuals throughout the year, but this was expected because there were no other marked individuals close to her home range.

Temporal association in home range overlaps

Wolverines were present simultaneously, within $24 \mathrm{~h}$, in only $30 \%$ of overlapping FK home ranges $(n=40)$. With MCP95 home ranges, the corresponding numbers were four

Table 1 Home range sizes of radiotracked wolverines (1993-2000) estimated with the minimum convex polygon method (MCP100 and MCP95) and the fixed kernel method (FK95)

\begin{tabular}{lllllllll}
\hline Sex (status) & Age & Number & $\begin{array}{l}\text { Number of telemetry } \\
\text { locations }\end{array}$ & MCP100 & MCP95 & FK95 & FK50 & Autocorrelation \\
\hline Females (reproducing) & Adult & 15 & $29(2)$ & $131(34)$ & $99(23)$ & $170(51)$ & $30(10)$ & $1.7(0.1)$ \\
Females (barren) & Adult & 9 & $30(2)$ & $132(58)$ & $104(45)$ & $171(63)$ & $24(10)$ & $1.7(0.2)$ \\
Females & Subadult & 1 & 16 & 42 & 23 & 51 & 11 & 1.7 \\
Males & Adult & 4 & $26(1)$ & $403(53)$ & $434(143)$ & $669(211)$ & $105(38)$ & $1.4(0.2)$ \\
Males & Subadult & 3 & $23(5.1)$ & $140(35)$ & $110(26)$ & $165(23)$ & $66(47)$ & $1.7(0.3)$ \\
\hline
\end{tabular}

Fifty percent fixed kernel contours (FK50) were used to estimate core areas of home ranges. All home range estimates are given as mean square kilometre $( \pm \mathrm{SE})$. Autocorrelation (Schoener's index) and number of telemetry positions are given as mean $( \pm \mathrm{SE})$ 
Table 2 Home range overlaps of radiotracked wolverines (1993-2000) estimated with the fixed kernel method using the 95\% (FK95) and 50\% contours (FK50) and minimum convex polygon method (MCP95)

\begin{tabular}{|c|c|c|c|c|c|c|c|c|c|}
\hline \multirow[t]{2}{*}{ Dyad } & \multicolumn{3}{|l|}{ FK95 } & \multicolumn{3}{|l|}{ МСР95 } & \multicolumn{3}{|l|}{ FK50 } \\
\hline & Number & Area & Proportion & Number & Size & Proportion & Number & Size & Proportion \\
\hline 우우 & 20 & $14(3)$ & $0.09(0.07)$ & 6 & $10(5)$ & 0.09 & 1 & 0.1 & 0.02 \\
\hline jo+ & 10 & $66(24)$ & $0.17(0.15)$ & 3 & $109(57)$ & 0.29 & 0 & & \\
\hline 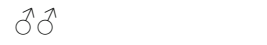 & 0 & & & 0 & & & 0 & & \\
\hline Subadult $q$-Adult ㅇ & 0 & & & 0 & & & 0 & & \\
\hline Subadult $q$-Adult $\widehat{o}$ & 0 & & & 0 & & & 0 & & \\
\hline Subadult $\hat{\jmath}$-Adult $\widehat{\partial}$ & 2 & $113(51)$ & $0.29(0.13)$ & 1 & 46 & 0.17 & 1 & 12 & 0.09 \\
\hline Subadult $\widehat{\partial}$-Adult ㅇ & 8 & $23(7)$ & $0.20(0.22)$ & 3 & $22(8)$ & 0.40 & 2 & $3(2)$ & 0.11 \\
\hline
\end{tabular}

Overlap sizes are given as mean area (square kilometre; $\pm \mathrm{SE})$ and mean proportion $( \pm \mathrm{SE})$. Dyad types consider adults if nothing else are given

out of 13 overlaps (31\%). Temporal association generally resulted in low simple ratio index values compared to the reference index (Table 3).

Adult males and females showed the highest temporal association (0.11). On seven different occasions (2 and 5 days, respectively), two pairs were recorded simultaneously in the overlap area. Association took place during May and July (Fig. 2). When home ranges were analysed with the MCP95 method, association between adult males and females was also recorded in August.

Temporal association was found on five occasions in home range overlaps of four adult females. The association

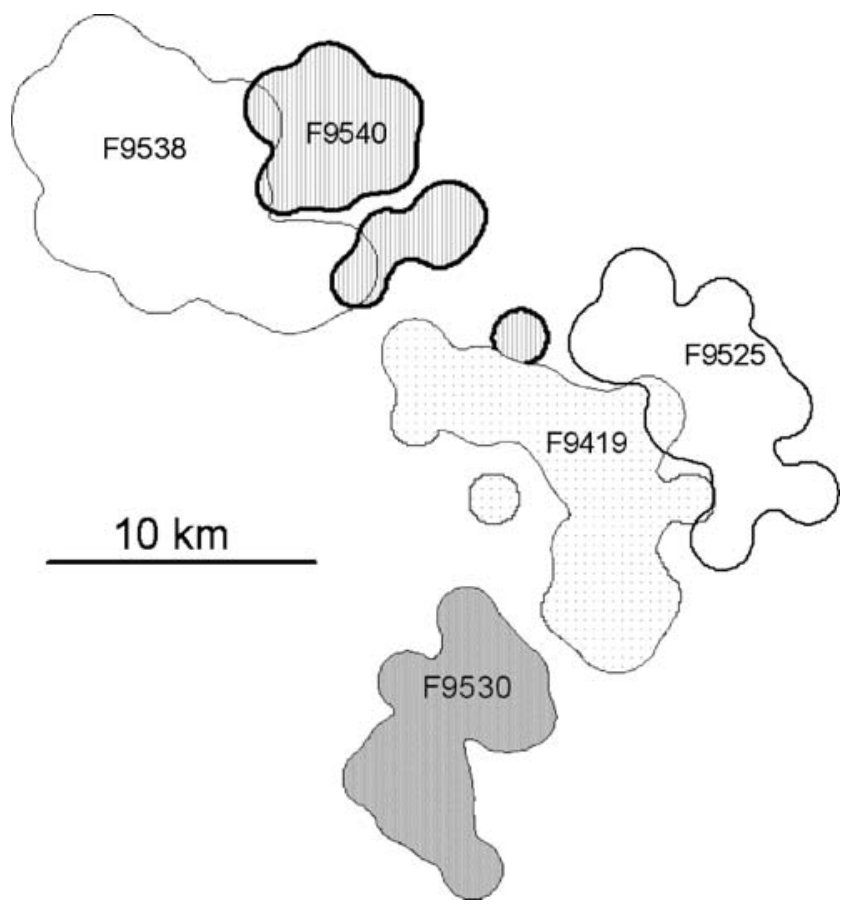

Fig. 1 Spatial distribution of five adult female wolverine home ranges (fixed kernel 95\%) and their overlap during 1995 in Sarek, northern Sweden index was relatively low (0.06). Overlaps were often caused by short visits into the neighbouring home range, resulting in a low temporal association. Temporal association was recorded from July to December (Fig. 2).

Temporal association was found between three subadult males and five adults. One subadult male stayed for most of the year within an adult male home range, resulting in an index value of 0.074 . Both individuals were recorded twice simultaneously in the overlap, one time in April and one time in August. Another four cases of temporal associations were found between four adult females and two subadult males, resulting in a relatively low index value of 0.065 . Temporal association took place during February to September.

\section{Discussion}

Home range size

Wolverines in our study showed considerable variation in home range size, within and among age and sex groups, ranging from $25-1,246 \mathrm{~km}^{2}$. Mean annual home range size of adult males $\left(669 \mathrm{~km}^{2}\right)$ was significantly larger than those of females $\left(170 \mathrm{~km}^{2}\right)$. Home range sizes in this study are within the range of those of North American wolverines, although variation is large within and among studies (Appendix). Variation in home range sizes among studies may partly be related to differences in area characteristics such as abundance and distribution of food, but also differences in data collection, analyses, and sample sizes (Banci 1994; Harestad and Bunnell 1979).

Male wolverines had 3.9 times larger home ranges than females. This agrees with the polygamous mating system (Hedmark et al. 2007) and the social organisation of most solitary carnivores (Sandell 1989). Hence, male home range size is expected to be influenced by the density of females. It has been suggested that males increase their movements during 
Table 3 Temporal association recorded in home range overlaps of radiotracked wolverines (1993-2000)

\begin{tabular}{|c|c|c|c|c|c|c|}
\hline \multirow[t]{2}{*}{ Dyad } & \multicolumn{2}{|l|}{ FK95 } & \multicolumn{2}{|l|}{ МСР95 } & \multicolumn{2}{|l|}{ FK50 } \\
\hline & $\begin{array}{l}\text { Number of temporal } \\
\text { association/total }\end{array}$ & $\begin{array}{l}\text { Simple ratio } \\
\text { index }\end{array}$ & $\begin{array}{l}\text { Number of temporal } \\
\text { association/total }\end{array}$ & $\begin{array}{l}\text { Simple ratio } \\
\text { index }\end{array}$ & $\begin{array}{l}\text { Number of temporal } \\
\text { association/total }\end{array}$ & $\begin{array}{l}\text { Simple ratio } \\
\text { index }\end{array}$ \\
\hline 우우 & $4 / 20(0.20)$ & 0.056 & $0 / 20$ & - & $0 / 20$ & - \\
\hline$\widehat{\partial}$ 우 & $2 / 9(0.22)$ & 0.114 & $2 / 9(0.22)$ & 0.139 & $0 / 9$ & - \\
\hline$\widehat{\partial}$ & $0 / 0$ & - & $0 / 0$ & - & $0 / 0$ & - \\
\hline Subadult $q$-Adult $q$ & $0 / 0$ & - & $0 / 0$ & - & $0 / 0$ & - \\
\hline Subadult $\phi$-Adult $\widehat{\partial}$ & $0 / 0$ & - & $0 / 0$ & - & $0 / 0$ & - \\
\hline Subadult $\widehat{\partial}$-Adult $\widehat{\partial}$ & $1 / 2(0.50)$ & 0.074 & $0 / 2$ & - & $0 / 2$ & - \\
\hline Subadult $\hat{\delta}$-Adult $q$ & $4 / 8(0.50)$ & 0.065 & $2 / 8(0.25)$ & 0.103 & $0 / 8$ & - \\
\hline Reference index & $6 / 6(1.0)$ & 0.571 & & & & \\
\hline
\end{tabular}

Number of overlaps where temporal association was found is compared to the total number of overlaps (parenthesis). Temporal association among dyads is compared to a reference index (juveniles-mothers) representing high association. Temporal associations were recorded in home range overlaps calculated with the fixed kernel method with 95\% (FK95) and 50\% (FK50) contours and the minimum convex polygon method (MCP95)

the mating season (Hornocker and Hash 1981; Copeland 1996) possibly influencing annual range size. Female home range size is assumed to be related to distribution and availability of food (Magoun 1985; Banci 1994).

Both home range size and core areas of reproducing females were similar to that of barren females, even though the majority of telemetry locations were taken during the cubrearing period (March to August). In contrast, previous studies suggest that females with offspring restrict their movements resulting in smaller home ranges (Magoun 1985; Banci 1994; Copeland 1996). It can be problematic to determine home range size for wolverine individuals without known residency status, and it is possible that previous studies include transient females in estimates of

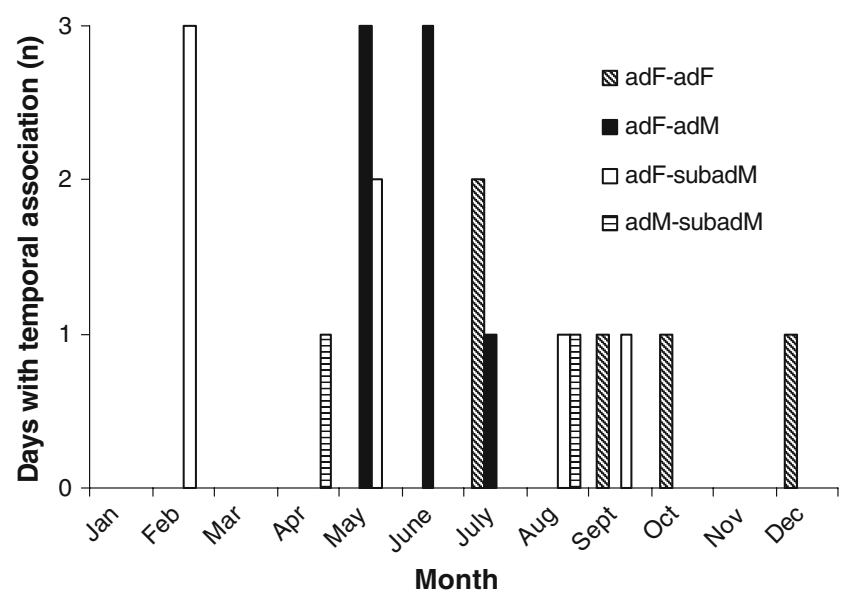

Fig. 2 Number of days and monthly distribution of temporal association recorded in home range overlaps (FK95) of wolverines in Sarek, northern Sweden (1993-2000). Dyads: $a d F$ adult female, adM adult male, and subadM subadult male barren female home ranges (e.g., Hornocker and Hash 1981), which could explain larger home range sizes in barren females than reproducing females in previous studies. In this study, we included only females of known residency status in the analyses. Two reproductive females lost their cubs in April to May and would therefore only be restricted in their movements during a short period. They did not, however, have larger home ranges than other reproductive females. Furthermore, our study population is largely saturated with female territories giving little room for females to expand home ranges years without offspring if we assume territoriality. In lower density populations, home ranges might be more flexible between years. Two females in this study had unusually large home ranges (603 and $805 \mathrm{~km}^{2}$ ). This was presumably the result of extraterritorial excursions preceding territory shifting the following year. However, excluding these females from the home range analysis did not affect the results significantly.

Home range overlaps

As expected, adult males and females had relatively large home range overlaps. One male partly covered home ranges of five adult females, and another male had three females within his home range. Similarly, one adult male in Alaska covered four to six females (Magoun 1985), and male home ranges encompassed those of three different females in Yukon and Idaho, respectively (Banci 1987; Copeland 1996). This suggests that female home ranges underlie the distribution of male home ranges in accordance with the wolverine mating system (Hedmark et al. 2007).

Home ranges of adult males were found to be exclusive. Sandell (1989) suggested that evenly distributed resources for males (i.e., females) may explain exclusive home 
ranges. Adult female home ranges were basically distributed border-to-border. Adult females had small overlaps, and core areas were always exclusive. This is consistent with previous studies where females maintained home ranges essentially exclusive throughout the year (Magoun 1985; Banci 1987; Copeland 1996). However, a relatively large overlap $\left(26 \mathrm{~km}^{2}\right)$ was found between two reproducing females. Genetic analyses showed that these two females were most likely mother and daughter (Hedmark et al. 2007), presumably explaining greater tolerance.

Subadult and adult home ranges showed relatively large overlaps, similar to previous studies (Magoun 1985; Banci 1987; Copeland 1996). Adults seem to be tolerant towards subadults of the opposite sex. Furthermore, at least four out of ten subadult-adult overlaps were between closely related individuals. Of two opposite sex overlaps, one was between father and son, and three relatively large overlaps between subadult males and adult females were mother-son associations. In addition to opposite sex tolerance and kinship, it is possible that tolerance is given to subadults because they are of lower rank than adults and not considered competitors. Genovesi et al. (1997) suggested that spatial behaviour in stone martens (Martes foina) is influenced by age-related social ranking. Erlinge (1977) showed that resident adult and dominant male stouts (Mustela erminea) were relatively unconcerned with subadult males within their home ranges. However, juvenile and subadult wolverines are occasionally killed by conspecifics (Persson et al. 2003; Lofroth 2001), suggesting that non-related wolverines of all ages can be seen as competitors.

\section{Temporal association}

Temporal association indicates whether wolverines avoid each other in space and time. We found temporal association in only $30 \%$ of all home range overlaps in the population. Temporal association generally showed low values (Table 3) indicating strong territoriality and that home range overlaps were caused by few and brief visits into neighbouring home ranges, when the owners were in another part of its home range. However, low values of temporal association could be a result of relatively few telemetry locations.

Temporal association between adult males and females were documented from May to July. This coincides with the mating season (Rausch and Pearson 1972). Temporal associations between adult females were found from July to December. Landa et al. (1998) showed that resident females increase their activity in late fall (September to November) when their offspring were independent. It is also possible that increased movement at this time is related to foraging and food hoarding, before the winter, as food availability during winter is critical for female wolverine reproductive success (Persson 2005).
Maintenance of territoriality

Wolverines are assumed to keep home ranges separated in space and time by marking the boundaries with scent, urine, and excrements (Koehler et al. 1980). In addition, direct aggression presumably an important role in maintaining exclusive territories. Juvenile (Persson et al. 2003) and adult females (Persson et al. 2009) are killed by conspecifics. Persson et al. (2003) suggested that unrelated territorial females killed four juvenile females when they left their maternal home ranges in August to September. Furthermore, adult males frequently exhibit fresh scars and wounds during the mating season (Magoun 1985; Wedholm 2006), and intraspecific mortality among subadult and adult males have been documented during the mating season (Lofroth 2001; Persson et al. 2009), which suggests that males become aggressive and intolerant of intruders during the mating season. Hence, assuming that intraspecific strife primarily involves individuals of the same sex, we suggest that both male and female wolverines use aggression to defend their territories. Because males and females compete for different resources, it seems plausible that aggression is pronounced at different times of the year for each sex.

\section{Conclusion}

Knowledge of wolverine space use and social organisation derived from this study increases our understanding of why and how individuals are distributed in a wolverine population. Knowledge of home range size and use is necessary for deciding appropriate management scale for the species. Understanding home range size and territoriality can help us to predict effects of management actions, such as harvest. It can also contribute to improvements of monitoring methods. More research is needed to find what specific resources or social attributes (e.g., kinship) determine territorial behaviour and dynamics. Identifying these attributes could simplify conservation of wolverines, e.g., understanding the consequences of removal of individuals and how this affects the stability within populations. Advances in DNA-identification techniques and the development of global positioning system transmitters will give opportunities to study territoriality in more detail.

Acknowledgements This study was financially supported by the Swedish Environmental Protection Agency, Norwegian Directorate for Nature Management, World Wildlife Fund Sweden, and the Kempe Foundation. The study was approved by the Animal Ethics Committee for northern Sweden, Umeå. We thank an anonymous reviewer for comments on the manuscript. 


\section{Appendix}

Table 4 Annual home ranges (square kilometre) of wolverine in different study areas

All estimates are MCP100, unless nothing else is given

${ }^{\text {a }}$ Estimated with MCP95

${ }^{\mathrm{b}}$ Estimates derived from logarithmic curve analyses of home range size vs time of monitoring

${ }^{\mathrm{c}}$ Estimated on locations from more than 1 year

${ }^{\mathrm{d}}$ Estimates based on snow-tracking

${ }^{\mathrm{e}}$ Estimates excluding long excursions

\begin{tabular}{|c|c|c|c|c|}
\hline Location & Number & Mean & Range & Reference \\
\hline \multicolumn{5}{|l|}{ Adult males } \\
\hline Idaho, USA & 5 & $1,506^{\mathrm{a}}$ & $953-2,400$ & Copeland 1996 \\
\hline NW Alaska, USA & 4 & 666 & $488-917$ & Magoun 1985 \\
\hline SC Norway & 4 & 663 & $502-942$ & Landa et al. 1998 \\
\hline SC Alaska, USA & 4 & $535^{\mathrm{b}}$ & $340-620$ & Whitman et al. 1986 \\
\hline N Sweden & 6 & 510 & $133-1,131$ & This study \\
\hline Montana, USA & 3 & $422^{\mathrm{c}}$ & - & Hornocker and Hash 1981 \\
\hline SW Yukon, Canada & 1 & $238^{\mathrm{e}}$ & - & Banci 1987 \\
\hline \multicolumn{5}{|c|}{ Adult reproducing females } \\
\hline Idaho, USA & 2 & $273^{\mathrm{a}}$ & $107-438$ & Copeland 1996 \\
\hline N Sweden & 3 & $170^{\mathrm{d}}$ & $109-221$ & Bjärvall 1982 \\
\hline N Sweden & 15 & 131 & $31-560$ & This study \\
\hline SC Alaska, USA & 3 & $105^{\mathrm{b}}$ & $60-120$ & Whitman et al. 1986 \\
\hline NW Alaska, USA & 3 & 73 & $55-99$ & Magoun 1985 \\
\hline SW Yukon, Canada & 1 & $47^{\mathrm{e}}$ & - & Banci 1987 \\
\hline \multicolumn{5}{|l|}{ Adult barren females } \\
\hline SC Norway & 4 & 335 & $273-397$ & Landa et al. 1998 \\
\hline Idaho, USA & 4 & $320^{\mathrm{a}}$ & $108-413$ & Copeland 1996 \\
\hline SW Yukon, Canada & 2 & $155^{\mathrm{e}}$ & $153-157$ & Banci 1987 \\
\hline NW Alaska, USA & 6 & 126 & $56-232$ & Magoun 1985 \\
\hline N Sweden & 9 & 132 & $45-576$ & This study \\
\hline \multicolumn{5}{|l|}{ Subadult males } \\
\hline SW Yukon & 3 & 534 & $438-619$ & Banci 1987 \\
\hline Idaho & 1 & 526 & & Copeland 1996 \\
\hline N Sweden & 3 & 140 & 76-196 & This study \\
\hline \multicolumn{5}{|l|}{ Subadult females } \\
\hline SW Yukon & 2 & 476 & $370-582$ & Banci 1987 \\
\hline SC Norway & 1 & 153 & & Landa et al. 1998 \\
\hline NW Alaska, USA & 1 & 53 & & Magoun 1985 \\
\hline N Sweden & 1 & 42 & & \\
\hline
\end{tabular}

\section{References}

Ackerman BB, Leban FA, Samuel MD, Garton EO (1990) User's manual for program HOME RANGE. Technical Report 15, Forestry, Wildlife and Range Experiment Station. University of Idaho, Moscow

Adams EA (2001) Approaches to the study of territory size and shape. Ann Rev Ecolog Syst 32:277-303

Arnemo JM, Fahlman $\AA$ (2007) Biomedical protocol for free-ranging brown bears, gray wolves, wolverines and lynx. Norwegian School of Veterinary Science, Tromsø, Norway. http://www4. nina.no/skandlo/pdf/Biomedical $\% 20$ protocols $\% 20$ carnivores $\%$ 20210807.pdf. Accessed 12 Jan 2009

Banci V (1987) Ecology and behaviour of wolverine in Yukon. M.Sc. thesis, Simon Fraser University, Burnaby, Canada

Banci V (1994) Wolverine. In: Ruggiero LF, Aubry KB, Buskirk SW, Lyon LJ, Zielinski WJ (eds) The scientific basis for conserving forest carnivores. American marten, fisher, lynx and wolverine in the western United States. General Technical Report RM254. U.S. Department of Agriculture, Forest Service, Rocky Mountain Forest and Range Experiment Station, Fort Collins, USA, pp 99-127

Bjärvall A (1982) A study of the wolverine female during the denning period. Transactions of the International Congress of Game Biologists 14:315-322

Brown JL, Orians GH (1970) Spacing patterns in mobile animals. Ann Rev Ecolog Syst 1:239-262

Burt WH (1943) Territoriality and home range concepts as applied to mammals. J Mammal 24:346-352

Cairns SJ, Schwager SJ (1987) A comparison of association indices. Anim Behav 35:454-1469

Copeland JP (1996) Biology of the wolverine in central Idaho. M.Sc. thesis, University of Idaho, Moscow, USA 
Dahl F, Willebrand T (2005) Natal dispersal, adult home ranges and site fidelity of mountain hares Lepus timidus in the boreal forest of Sweden. Wildlife Biol 11:309-317

Erlinge S (1977) Spacing strategy in stout Mustela erminea. Oikos 28:32-42

Flagstad Ø, Hedmark E, Landa A, Brøseth H, Persson J, Andersen R, Segerström P, Ellegren H (2004) Colonization history and noninvasive monitoring of a re-established wolverine population. Conserv Biol 18:1-13

Gärdenfors U (2000) How are species redlisted? Manual and guidelines. Artdatabanken, SLU, Uppsala, Sweden

Genovesi P, Sinibaldi I, Boitani L (1997) Spacing patterns and territoriality of the stone marten. Can J Zool 75:1966-1971

Ginsberg JR, Young T (1992) Measuring association between individuals or groups in behavioural studies. Anim Behav 44:377-379

Grundsten C (1997) The Laponian area: a world heritage site. Swedish Environmental Protection Agency. Fälths Tryckeri AB, Stockholm, Sweden

Harestad AS, Bunnell FL (1979) Home range and body weight - a reevaluation. Ecology 60:389-402

Harris S, Creswell WJ, Forde PG, Trewhella T, Woollard T, Wray S (1990) Home-range analysis using radio-tracking data-a review of the problems and techniques particularly as applied to the study of mammals. Mamm Rev 20:97-123

Hedmark E, Persson J, Segerström P, Landa A, Ellegren H (2007) Paternity and mating system in wolverines Gulo gulo. Wildlife Biol 13(Suppl 2):13-30

Hooge PN, Eichenlaub B (1997) Animal Movement Extension to arcview, Ver. 1.1. Alaska Biological Science Center, US Geological Survey, Anchorage, AK

Hornocker MG, Hash HS (1981) Ecology of the wolverine in northwestern Montana. Can J Zool 59:1286-1301

SAS Institute (2000) SAS/STAT user's guide, version 6. SAS Institute, Cary, $\mathrm{NC}$

Kenward R (2001) Wildlife radio tagging: equipment, field techniques and data analysis. Academic, London

Kernohan BJ, Gitzen RA, Millspaugh JJ (2001) Analysis of animal space use and movements. In: Millspaugh JJ, Marzluff JM (eds) Radio tracking and animal populations. Academic, San Diego, pp 125-166

Koehler GM, Hornocker MG, Hash HS (1980) Wolverine marking behaviour. Can Field-Nat 94:339-341

Krebs J, Lofroth E, Copeland J, Banci V, Cooley D, Golden H, Magoun A, Mulders R, Shults B (2004) Synthesis of survival rates and causes of mortality in North American wolverines. J Wildl Manage 68:493-502

Landa A, Strand O, Linell JDC, Skogland T (1998) Home-range sizes and altitude selection for arctic foxes and wolverines in an alpine environment. Can J Zool 76:448-457

Landa A, Linell JDC, Lindén M, Swenson JE, Røskaft E, Moksnes A (2000) Conservation of Scandinavian wolverines in ecological and political landscapes. In: Griffiths HI (ed) Mustelids in a modern world. Management and conservation aspects of small carnivore: human interactions. Backhuys Publishers, Leiden, pp 1-20

Lofroth EC (2001) Northern wolverine project: 2000/01 year end report. Forest renewal activity no. $712260, \mathrm{BC}$

Magoun AJ (1985) Population characteristics, ecology and management of wolverines in nortwestern Alaska. Ph.D. dissertation, University of Alaska, Fairbanks, USA

Maher CR, Lott DF (1995) Definitions of territoriality used in the study of variation in vertebrate spacing systems. Anim Behav 49:1581-1597

Minta SC (1992) Tests of spatial and temporal interaction among animals. Ecol Appl 2:178-188

Mohr CO (1947) Table of equivalent populations of North American small mammals. Am Midl Nat 37:223-249
Mustelid Specialist Group (1996) Gulo gulo. In: IUCN 2006. 2006 IUCN red list of threatened species. www.iucnredlist.org

Noble GK (1939) The role of dominance in the social life of birds. Auk 56:263-273

Persson J (2005) Female wolverine reproduction: reproductive costs and winter food availability. Can J Zool 83:1453-1459

Persson J (2007) Status and ecology of the wolverine in Sweden. Report to the Carnivore Commission 2007. www.sou.gov.se/ storarovdjur/PDF/Artbeskrivning\%20j\%C3\%A4rv\%20v5.pdf

Persson J, Willebrand T, Landa A, Andersen R, Segerström P (2003) The role of intraspecific predation in the survival of juveniles wolverines Gulo gulo. Wildlife Biol 9:21-28

Persson J, Landa A, Andersen R, Segerström P (2006) Reproductive characteristics of female wolverines (Gulo gulo) in Scandinavia. J Mammal 87:75-79

Persson J, Ericsson G, Segerström P (2009) Human caused mortality in the endangered Scandinavian wolverine population. Biol Conserv 142:325-331

Powell RA (1979) Mustelid spacing patterns: variations on a theme by Mustela. Z Tierpsychol 50:153-165

Powell RA (2000) Animal home ranges and home range estimators. In: Boitani L, Fuller TK (eds) Research techniques in animal ecology controversies and consequences. Columbia University Press, New York, pp 65-110

Rausch RA, Pearson AM (1972) Notes on wolverine in Alaska and the Yukon territory. J Wildl Manage 36:249-268

Rodgers AR, Carr AP (1998) HRE: The Home Range Extension for ArcView. Ontario Ministry of Natural Resources, Centre for Northern Forest Ecosystem Research, Thunder Bay, ON

Sandell M (1989) The mating tactics and spacing patterns of solitary carnivores. In: Gittleman JL (ed) Carnivore, behaviour, ecology and evolution. Cornell University Press, New York, pp 164-182

Schoener TW (1968) Sizes of feeding territories among birds. Ecology 49:123-141

Schoener TW (1981) An empirically based estimate of home range. Theor Popul Biol 20:281-325

Seaman DE, Millspaugh JJ, Kernohan BJ, Brundige GC, Raedke KJ, Gitzen RA (1999) Effects of sample size on kernel home range estimates. J Wildl Manage 63:739-747

Siegel S, Castellan JN (1988) Nonparametric statistics for the behavioural sciences. McGraw-Hill Inc, USA

Slough B (2007) Status of the wolverine Gulo gulo in Canada. Wildlife Biol 13(Suppl 2):76-82

Swenson JE, Andrén H (2005) A tale of two countries: large carnivore depredations and compensation schemes in Sweden and Norway. In: Woodroffe R, Thirgood S, Rabinowitz A (eds) People and wildlife: conflict or co-existence?. Cambridge University Press, Cambridge, pp 323-339

Swihart RK, Slade NA (1985) Testing for independence of in animal movements. Ecology 66:1176-1184

Vangen MK, Persson J, Landa A, Andersen R, Segerström P (2001) Characteristics of dispersal in wolverines. Can J Zool 79:1641-1649

Wedholm P (2006) Territoriallity and social organization in Scandinavian wolverines Gulo gulo. M.Sc. thesis, Swedish University of Agricultural Sciences, Umeå, Sweden

White GC, Garrott RA (1990) Analysis of wildlife radio-tracking data. Academic, San Diego

Whitman JS, Ballard WB, Gardner CL (1986) Home range and habitat use by wolverines in south central Alaska. J Wildl Manage 50:460-463

Worton BJ (1989) Kernel methods for estimating the utilization distribution in home-range studies. Ecology 70:164-168

Zhang M, Liu Q, Piao R, Jiang G (2007) The wolverine Gulo gulo population in the Great Kinghan Mountains, northeastern China. Wildlife Biol 13(Suppl 2):83-88 